Article

\title{
Evidence of IgE-Mediated Cross-Reactions between Anisakis simplex and Contracaecum osculatum Proteins
}

\author{
Foojan Mehrdana ${ }^{1}$, María Lavilla ${ }^{2}{ }^{\mathbb{D}}$, Per Walter Kania ${ }^{1}$, Miguel Ángel Pardo ${ }^{2}$, María Teresa Audicana ${ }^{3}$, \\ Natividad Longo ${ }^{3}$ and Kurt Buchmann ${ }^{1, *(D)}$ \\ 1 Laboratory of Aquatic Pathobiology, Veterinary and Animal Sciences, Faculty of Health and Medical Sciences, \\ University of Copenhagen, 1870 Frederiksberg C, Denmark; foojan@sund.ku.dk (F.M.); \\ pwk@sund.ku.dk (P.W.K.) \\ 2 AZTI-BRTA, Food Research, Parque Tecnológico de Bizkaia, Astondo Bidea-Edificio 609, \\ E-48160 Derio, Spain; mlavilla@azti.es (M.L.); mpardo@azti.es (M.Á.P.) \\ 3 Allergy Department, Araba Integrated Health Organization, Bioaraba.Osakidetza, Basque Health Service, \\ Jose Atxotegui s/n, E-01009 Vitoria, Spain; \\ MARIATERESA.AUDICANABERASATEGUI@osakidetza.eus (M.T.A.); \\ MARIANATIVIDAD.LONGOARESO@osakidetza.eus (N.L.) \\ * Correspondence: kub@sund.ku.dk; Tel.: +45-35-33-27-00
}

Citation: Mehrdana, F.; Lavilla, M.; Kania, P.W.; Pardo, M.Á.; Audicana, M.T.; Longo, N.; Buchmann, K. Evidence of IgE-Mediated CrossReactions between Anisakis simplex and Contracaecum osculatum Proteins. Pathogens 2021, 10, 950. https:// doi.org/10.3390/pathogens10080950

Academic Editor: Fabrizio Bruschi

Received: 14 June 2021

Accepted: 24 July 2021

Published: 28 July 2021

Publisher's Note: MDPI stays neutral with regard to jurisdictional claims in published maps and institutional affiliations.

Copyright: (c) 2021 by the authors. Licensee MDPI, Basel, Switzerland. This article is an open access article distributed under the terms and conditions of the Creative Commons Attribution (CC BY) license (https:// creativecommons.org/licenses/by/ $4.0 /)$.

\begin{abstract}
Fish consumers may develop allergic reactions following the ingestion of fish products containing nematode larvae within the genus Anisakis. Sensitized patients may cross-react with proteins from insects, mites and mollusks, leading to allergic reactions even in the absence of the offending food. Potential cross-reactivity in Anisakis-allergic patients with larval proteins from other zoonotic parasites present in freshwater and sea fish should be investigated due to an increasing occurrence in certain fish stocks, particularly Contracaecum osculatum. In this work, we evaluated IgEcross reactions by in vivo (skin prick tests with parasites extracts) and in vitro methods (IgE-ELISA and IgE-immunoblot). In vivo skin prick tests (SPT) proved the reactivity of Anisakis-sensitized patients when exposed to C. osculatum antigens. Sera from Anisakis-sensitized patients confirmed the reaction with somatic antigens (SA) and excretory/secretory proteins (ES) from C. osculatum. Only anecdotal responses were obtained from other freshwater worm parasites. Consequently, it is suggested that Anisakis-sensitized humans, especially patients with high levels of specific anti-Anisakis antibodies, may react to $C$. osculatum proteins, possibly due to IgE-mediated cross-reactivity.
\end{abstract}

Keywords: Anisakis simplex; Contracaecum osculatum; allergens; human IgE; freshwater parasites; cross-reactions

\section{Introduction}

Third-stage larvae (L3) of Anisakis simplex, a member of the nematode family Anisakidae, use a variety of marine fish species as transport hosts and marine mammals as final hosts. The ingestion of fish products carrying live nematode larvae is considered a public health issue as it may cause gastrointestinal disease (anisakiasis), and also triggers allergic reactions [1]. Allergic forms of the disease are associated with IgE-mediated hypersensitivity, including urticaria, angioedema and anaphylaxis [2].

Anisakis simplex antigens are known to cross-react with other allergens from other ascarid nematodes [3,4]. In addition, the somatic allergens Ani s 2 and Ani s 3 have been reported to cross-react with molecules from mites, crustaceans and mollusks [5-8]. Consequently, although this fact has not yet been described, it cannot be excluded that some cross-reactivity may also occur between proteins from other closely related anisakid nematodes, such as those belonging to the genera Pseudoterranova or Contracaecum. In particular, third-stage larvae of a species within the latter genus, C. osculatum (liver worm), have recently been reported to parasitize the liver of Atlantic cod (Gadus morhua) from the Baltic Sea with a prevalence of up to $100 \%[9,10]$, while the prevalence of Anisakis 
in this fish is much lower [11,12]. It is therefore relevant to analyze whether proteins from C. osculatum cross-react with Anisakis allergens, since the potential allergenicity of this parasite has not been described previously. The objective of this work was to assess the potential cross-reactivity of $C$. osculatum proteins with $A$. simplex sensitized patients. Several additional parasites of freshwater fish (trematodes) were also studied, since their proteins could act as a hidden source of allergens in fish.

\section{Materials and Methods}

\subsection{Parasites and Protein Preparations}

C. osculatum third-stage larvae were isolated from Atlantic cod livers (a Baltic subpopulation of Gadus morhua) caught by a local fisherman in the Southern Baltic Sea. The livers were kept at $3-5{ }^{\circ} \mathrm{C}$ and immediate isolation of worm larvae was performed by artificial digestion (pepsin $/ \mathrm{HCl} / \mathrm{NaCl}$ solution with magnetic stirring at $250 \mathrm{rpm}$ at $37^{\circ} \mathrm{C}$, using a volume of $10 \mathrm{~mL}$ solution per gram of fish liver). Following full digestion of the livers (1-2 h), the digest was filtered through a $300 \mu \mathrm{m}$ sieve, whereafter nematodes were collected.

A. simplex larvae (non-encapsulated) were collected from the body cavity of freshly caught North Sea herring (Clupea harengus) provided by a local fish shop (Frederiksberg, Denmark).

Trematodes (Tetracotyle sp., Apophallus sp. and Posthodiplostomum sp.) were collected from several freshwater fish provided by different local fishermen.

All the parasites above were identified by standard morphological methods. Total extracts (TE) were obtained from all parasites using the technique adapted from Perteguer et al. [13].

Excretory/secretory proteins (ES) from A. simplex and C. osculatum were collected as described previously [14,15]. In brief, worm larvae were washed several times in phosphate buffered saline (PBS, Dacos A/S, Esbjerg, Denmark) and then incubated at $37^{\circ} \mathrm{C}$ in sterile 12-well NunclonTM cell culture plates (WVR, Denmark) for five days. Each well contained 10 live larvae in $2.5 \mathrm{~mL}$ PBS with antibiotics $(200 \mu \mathrm{g} / \mathrm{mL}$ ampicillin and $400 \mathrm{\mu g} / \mathrm{mL}$ kanamycin sulphate) (Sigma-Aldrich, St. Louis, MO, USA). After incubation, the medium was filtered through $0.20 \mu \mathrm{m}$ Minisart ${ }^{\circledR}$ filters (Sigma-Aldrich) and stored at $-40{ }^{\circ} \mathrm{C}$ until further use.

In order to isolate somatic proteins (SA), recovered parasite larvae were homogenized for $4 \mathrm{~min}$ at a frequency of $20 \mathrm{~Hz}$ in a TissueLyser II (Qiagen, Hilden, Denmark) in PBS-containing protease inhibitors (5 mM ethylenediaminetetraacetic acid, $1 \mathrm{mM}$ phenylmethyl-sulphonyl fluoride and 0.1 trypsin inhibitor unit/mL aprotinin) [3]. The homogenates were centrifuged at $16,000 \mathrm{rpm}$ for $30 \mathrm{~min}$ at $4{ }^{\circ} \mathrm{C}$ and the supernatant was collected and preserved at $-20^{\circ} \mathrm{C}$ until use.

\subsection{Patient Sera}

Sera from 9 patients admitted to the Araba University Hospital (Allergy Department, Vitoria, Spain) with diagnosed A. simplex allergy (but not reporting previous anisakidosis or Anisakis infestation, according to their clinical records), and presenting high levels of specific anti-Anisakis IgE (higher than $30 \mathrm{kUA} / \mathrm{L}$ ) (ImmunoCAP FEIA System, ThermoFisher Scientific, Waltham, MA, USA) were collected. These sera were mixed (by equal volume of each serum), and this pool was used for specificity in vitro testing.

Negative control sera were obtained from healthy individuals without any allergy symptoms (2 patients) and from patients allergic to other food proteins but not to fish or A. simplex (10 patients). These patients were tested by skin prick tests (SPT) with an A. simplex extract with a negative result before using their sera for in vitro tests. Sera were tested later (in vitro tests) in two different pools (one for non-allergic and one for those allergic to other proteins). 


\subsection{Evaluation of Cross-Reactivity}

This work has been approved by the Ethics Committee for Clinical Research (CEIC) of the Araba Hospital (Vitoria, Spain) with internal ref. PI2018118. All participant patients gave written informed consent and patient anonymity has been secured through the entire study.

\subsubsection{Skin Prick Tests}

The skin prick tests (SPT) comprised two groups of $A$. simplex-sensitized individuals voluntarily recruited from local patients with an allergic reaction induced by the ingestion of fish dishes. Group 1: six patients classified as "low IgE" (L); sensitized but without allergic symptoms; positive SPT with $A$. simplex extract and positive low specific-IgE to $A$. simplex $(<2.5 \mathrm{kUA} / \mathrm{L})$. These patients had negative SPT and negative specific-IgE against fish extracts. Group 2: nine patients classified as "high IgE" (H), showing allergic symptoms, positive SPT with $A$. simplex extract and positive high specific-IgE to $A$. simplex (media value of $41.0 \mathrm{kUA} / \mathrm{L}$ of $A$. simplex-specific IgE, interquartile range: 30.5 to $62.9 \mathrm{kUA} / \mathrm{L}$ ). These patients had negative SPT and negative specific-IgE against fish extracts. Two non-allergic patients were evaluated as negative controls.

SPTs were performed in duplicate on the volar surface of each forearm by using a standard $1 \mathrm{~mm}$ tip lancet (ALK-Abelló), following the EAACI recommendations [16]. Histamine hydrochloride $(10 \mathrm{mg} / \mathrm{mL}$ ) and physiological serum (PSS) were used as positive and negative controls, respectively. Tests were performed with complete protein extracts (TE) from all species. The wheal areas were measured by assessing the diameters in millimeters $(\mathrm{mm})$ and wheal diameters $>3 \mathrm{~mm}$ were considered positive reactions.

\subsubsection{ELISA}

For the in vitro evaluation of cross-reactions between A. simplex and C. osculatum antigens, microtiter plates (microwell F96 PS Maxisorp, NUNC) were coated overnight at $4{ }^{\circ} \mathrm{C}$ with $100 \mu \mathrm{L}$ of a solution containing $5 \mu \mathrm{g} / \mathrm{mL}$ of the corresponding antigens: A. simplex (SA or ES) or C. osculatum (SA or ES) diluted in coating buffer $\left(15 \mathrm{mM} \mathrm{Na}_{2} \mathrm{CO}_{3}, 35 \mathrm{mM}\right.$ $\mathrm{NaHCO}_{3}$, sodium carbonate/bicarbonate buffer, $\mathrm{pH}$ 9.6). At this point, additional negative controls were also included to check for non-specific IgE-binding to wells by including wells with only a blocking buffer (no antigen). After blocking with $1 \%(w / v)$ bovine serum albumin (BSA, A7906, Sigma-Aldrich, St. Louis, MO, USA) in PBS (150 mM NaCl, $8 \mathrm{mM}$ $\mathrm{K}_{2} \mathrm{HPO}_{4}, 16 \mathrm{mM} \mathrm{KH} \mathrm{PO}_{4}, \mathrm{pH} 7.4$ ) for $1.5 \mathrm{~h}$ at room temperature (RT), the plates were incubated with pooled sera (each sample tested in quadruplicate) diluted 1:100 in PBS for $1 \mathrm{~h}$ at $37^{\circ} \mathrm{C}$. This dilution was selected based on prior optimization of the assay (data not shown). The plates were subsequently incubated with $100 \mu \mathrm{L}$ of a goat anti-human IgE-HRP (A9667 Sigma-Aldrich, St. Louis, MO, USA) (diluted 1:4000 in PBS) for $40 \mathrm{~min}$ at $37^{\circ} \mathrm{C}$. Unbound proteins were washed three times using PBST (PBS with $0.05 \%(w / v)$ Tween-20) between all the steps. A color reaction was developed by adding $100 \mu \mathrm{L}$ of tetramethylbenzidine (1-STEP ${ }^{\mathrm{TM}}$ Ultra TMB-ELISA SUBSTRATE, Thermo Scientific ${ }^{\mathrm{TM}}$ ) and stopped with $50 \mu \mathrm{L}$ of $2 \mathrm{M} \mathrm{H}_{2} \mathrm{SO}_{4}$. Optical density (OD) was measured at $450 \mathrm{~nm}$ using a microplate reader Thermo Scientific ${ }^{\mathrm{TM}}$ Varioskan Flash (Waltham, MA, USA).

\subsubsection{Gel Electrophoresis and Immunoblot}

Proteins were electrophoretically separated under reducing conditions on NuPAGE ${ }^{\circledR}$ Nove ${ }^{\circledR}$ Bis-Tris Gels (4-12\% polyacrylamide) using an XCell SurelockTM Mini-Cell (Invitrogen, Carlsbad, CA, USA) according to the manufacturer's instructions. Samples contained 54 and $30 \mu \mathrm{g}$ protein for SA and ES isolates, respectively. Separated proteins were transferred onto a nitrocellulose membrane in an XCell II Blot Module running at $30 \mathrm{~V}$ for $1 \mathrm{~h}$. Subsequently, the membrane was blocked in Tris-buffered saline containing $0.05 \%$ $(v / v)$ Tween 20 (TBS-T, pH 7.6) and 5\% (w/v) skimmed milk powder (SMP), whereafter it was incubated in human sera (diluted 1:4 with TBS-T and 5\% $(v / v)$ SMP) overnight at RT. Following each step, the membrane was washed $(3 \times 10 \mathrm{~min})$ with TBS-T. The 
next incubation applied a monoclonal mouse anti-human IgE (diluted 1:250, clone GE-1, ascites fluid, Sigma-Aldrich) for $2 \mathrm{~h}$ under agitation at RT. Following a washing step, the membrane was incubated in the goat anti-mouse IgG conjugated with HRP (diluted 1:500, Sigma-Aldrich) ( $2 \mathrm{~h}$ agitation at $\mathrm{RT})$. After a final wash, reactivity was visualized by adding substrate (AEC staining kit, Sigma-Aldrich).

\subsection{Statistical Analysis}

ELISA results were analyzed with two-way ANOVA followed by Tukey's Multiple Comparison test using GraphPad Prism version 7 and $p$-values $<0.05$ were considered statistically significant.

\section{Results}

Skin prick tests (SPT) showed that an important cross-reactivity may occur between proteins from Anisakis and Contracaecum parasite species (Table 1), while only anecdotal responses (minor responses in three patients, in all cases less intense than the histamine control and the target species of this work) were obtained from other freshwater worm parasites (data not shown).

Table 1. Wheal size (length $\times$ width in $\mathrm{mm}$ ) obtained by skin prick test (SPT) in patients allergic to Anisakis with low levels (L) of specific anti-Anisakis IgE ( $<2.5 \mathrm{kUA} / \mathrm{L}$ ) or high levels $(\mathrm{H})$ of specific anti-Anisakis $\operatorname{IgE}(>30 \mathrm{kUA} / \mathrm{L})$. N: negative (wheal size length and width less than $3 \mathrm{~mm}$ ).

\begin{tabular}{cccccc}
\hline & \multicolumn{2}{c}{ Right Arm } & \multicolumn{2}{c}{ Left Arm } \\
\hline Patient ID & IgE Level & Contracaecum & Anisakis & Contracaecum & Anisakis \\
\hline L1 & 1.2 & $\mathrm{~N}$ & $4 \times 3$ & $\mathrm{~N}$ & $5 \times 4$ \\
L2 & 2.3 & $\mathrm{~N}$ & $4 \times 3$ & $\mathrm{~N}$ & $4 \times 4$ \\
L3 & 1.1 & $\mathrm{~N}$ & $\mathrm{~N}$ & $\mathrm{~N}$ & $\mathrm{~N}$ \\
L4 & 0.9 & $3 \times 4$ & $3 \times 3$ & $4 \times 4$ & $4 \times 4$ \\
L5 & 1.2 & $6 \times 4$ & $5 \times 3$ & $\mathrm{~N}$ & $7 \times 4$ \\
L6 & 1.1 & $\mathrm{~N}$ & $3 \times 3$ & $\mathrm{~N}$ & $5 \times 6$ \\
H1 & 62.9 & $6 \times 4$ & $4 \times 4$ & $5 \times 4$ & $6 \times 4$ \\
H2 & 54.3 & $6 \times 5$ & $6 \times 5$ & $7 \times 5$ & $5 \times 5$ \\
H3 & 40.7 & $\mathrm{~N}$ & $12 \times 6$ & $\mathrm{~N}$ & $10 \times 6$ \\
H4 & 39.6 & $3 \times 3$ & $10 \times 6$ & $4 \times 5$ & $12 \times 7$ \\
H5 & 38.1 & $7 \times 4$ & $7 \times 5$ & $7 \times 5$ & $7 \times 5$ \\
H6 & 37.4 & $4 \times 4$ & $6 \times 5$ & $5 \times 3$ & $9 \times 7$ \\
H7 & 34.6 & $3 \times 4$ & $13 \times 6$ & $3 \times 3$ & $14 \times 6$ \\
H8 & 31.3 & $9 \times 7$ & $10 \times 7$ & $8 \times 7$ & $10 \times 7$ \\
H9 & 30.5 & $\mathrm{~N}$ & $3 \times 3$ & $\mathrm{~N}$ & $3 \times 5$ \\
\hline
\end{tabular}

Anisakis-sensitized patients reacted strongly both to A. simplex and C. osculatum proteins. However, there are differences in the level of reactivity depending on the patient sensitivity: as can be seen in Table 1, those patients with high levels of specific IgE to Anisakis $(\mathrm{H})$ reacted to $C$. osculatum to a greater extent (seven of nine patients) than patients sensitized to Anisakis with lower IgE levels (L), who also showed a lower reactivity to C. osculatum (two of six patients).

In vitro tests confirmed these results: ELISA results showed that human $\operatorname{IgE}$ in sera from Anisakis sensitized patients also binds to Contracaecum somatic antigens (SA) and excretory/secretory proteins (ES) components (Figure 1). No statistically significant difference in binding strength of $\operatorname{IgE}$ was recorded with regard to SA $(p=0.61)$ and ES proteins $(p=0.88)$ from the two worm species. Additionally, it was noted that the IgE-binding was significantly higher to ES proteins than to SA proteins in both A. simplex and C. osculatum species (1.6 times, $p<0.0001$ and 1.7 times, $p<0.0001$, respectively) (Figure 1). Residual IgE-binding was shown to parasite antigens when sera from other patients (non-allergic or allergic to other foods) were used, probably due to unspecific binding; nonetheless, it does not interfere with aforementioned specific reactions to parasites proteins. 


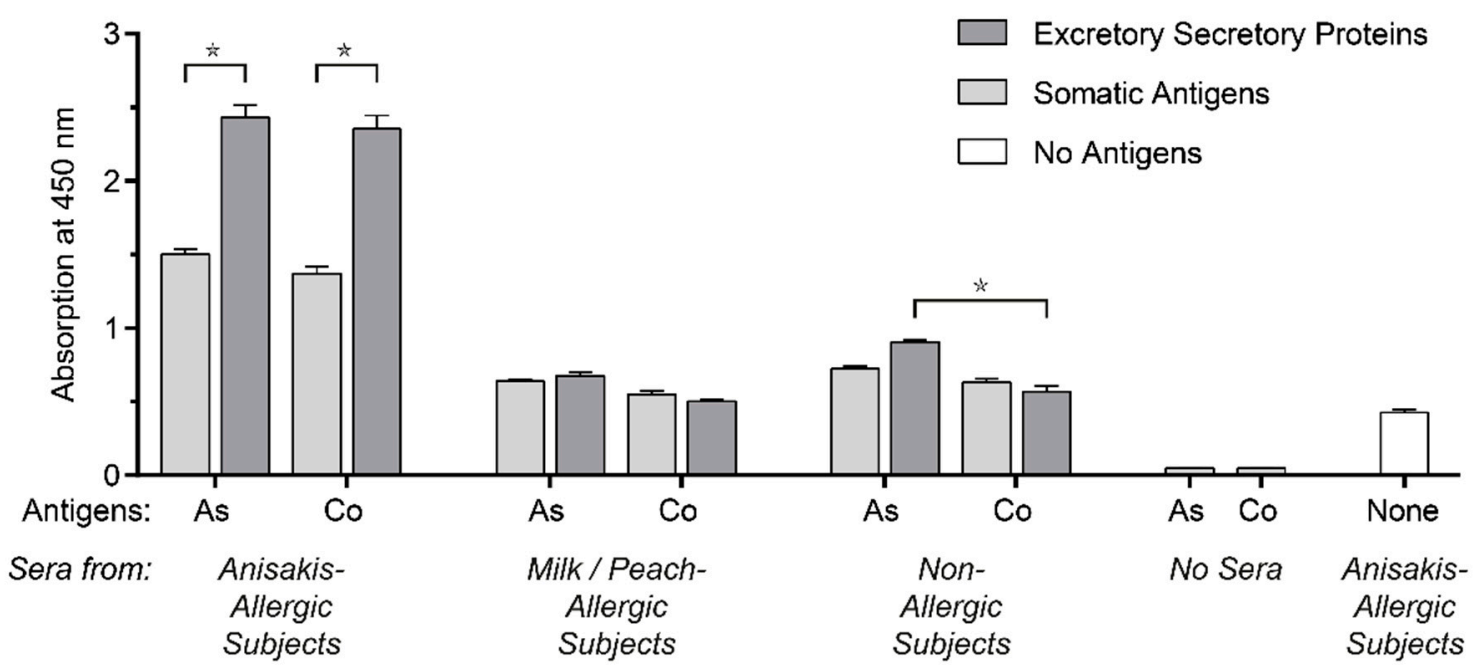

Figure 1. Binding of serum IgE to excretory/secretory proteins (dark gray columns) and somatic antigens (soft gray columns) from A. simplex (As) and C. osculatum (Co) measured by ELISA: (1) pooled serum from patients sensitized to A. simplex; (2) patients allergic to other food allergens; (3) non-allergic subjects. *: $p<0.0001$. Other negative controls (white columns) are also included.

Finally, Western blotting (WB) verified that $\operatorname{IgE}$ in sera from A. simplex sensitized patients bound to specific SA and ES antigens from both A. simplex and C. osculatum (Figure 2): The sera pool detected several SA from both parasites. Contrarily, only one dominant protein band (approximately MW $60 \mathrm{kDa}$ ) was evidenced from the Anisakis ES sample, whereas additional IgE-binding components were detected among Contracaecum ES proteins (MW from 19 to $330 \mathrm{kDa}$ ). Sera from non-allergic patients did not recognize any specific parasite protein (Figure 2).

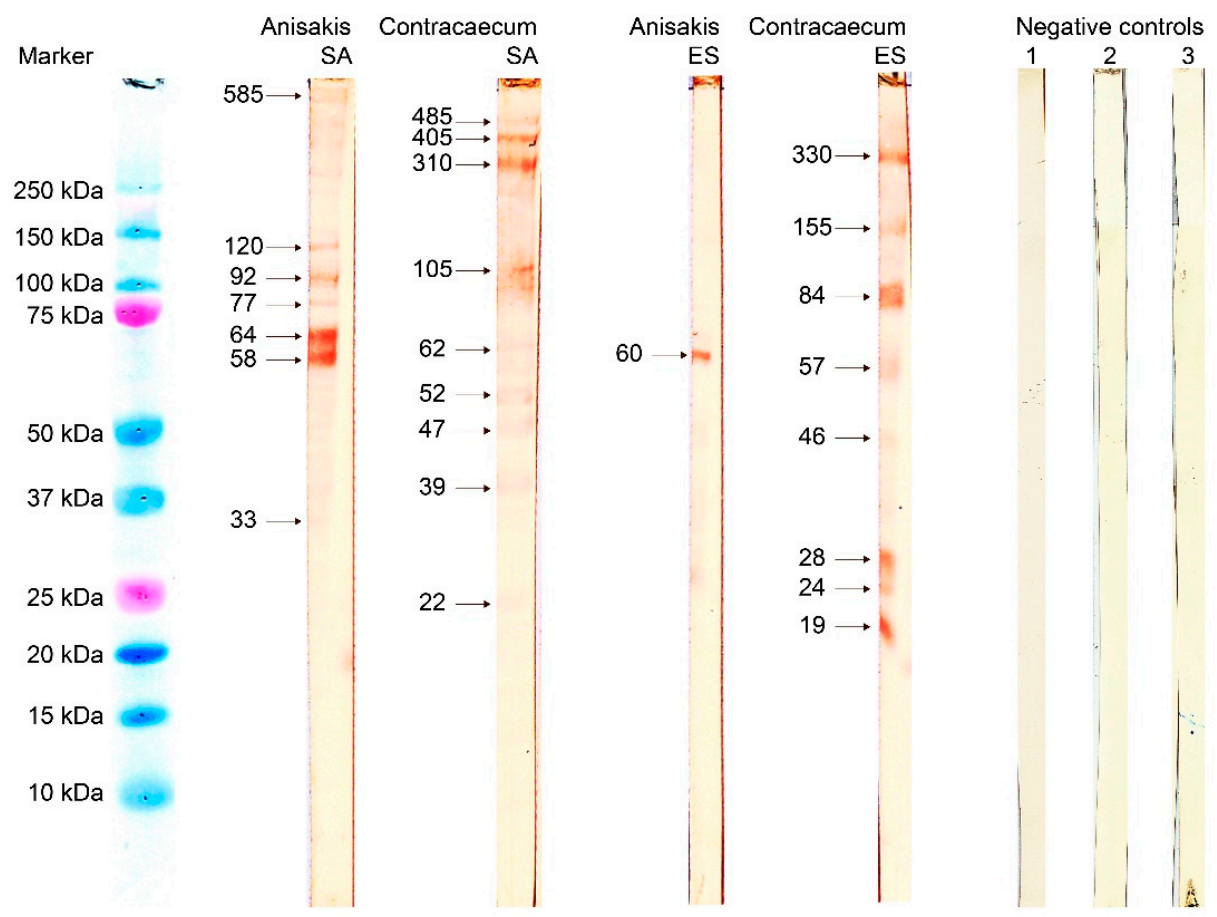

Figure 2. Immunoblot with isolated SA and ES proteins from A. simplex and C. osculatum third-stage larvae separated by SDS-PAGE (reducing conditions) and transferred to nitrocellulose. Reactions with IgE from pooled serum samples from patients sensitized to A. simplex. Marker: Precision Plus Protein ${ }^{\mathrm{TM}}$ Dual Color Standards. 


\section{Discussion}

It is well documented that $A$. simplex produces a number of allergenic proteins which are involved in its immunopathology $[2,14,17]$. As said previously, Anisakis simplex antigens are known to potentially cross-react with other allergens from, e.g., other ascarid nematodes [3,4] and with molecules from mites, crustaceans and mollusks [5-8]. However, although information on potential similar allergens in other anisakid nematodes has been hypothesized [18,19], and IgG antigenic homology among nematodes has been described previously $[3,18]$, in vivo and $\mathrm{IgE}$ cross-reactions between fish parasites within this family had not yet been studied. To our knowledge, this is the first time that IgE cross-reactivity between two related species, Anisakis simplex and Contracaecum osculatum, both present in fish, has been confirmed in some patients.

It is not known if fish products carrying C. osculatum larvae (live or killed) are able to induce IgE production in consumers. Relatively few infections of humans with this parasite have been published [20-23] and mice studies have indicated reduced allergenicity of Contracaecum proteins [24]. Moreover, the present study was performed with patients from Spain, where infections with Contracaecum have never been recorded [14,25]. All these facts indicate that the observed cross-reactivity by both in vivo and in vitro methods is due to a real potential cross-reactivity between the two parasites and not because of the presence of specific IgE against Contracaecum proteins in allergic patients' sera.

In our previous studies of allergy to Anisakis simplex, a correlation was observed between high levels of specific IgE, a high repertoire of bands recognized in Western blot and the severity of allergic reactions and anaphylaxis (severe allergy) [2]. This fact could explain why patients with high levels of specific IgE to Anisakis reacted more frequently and to a greater extent to $C$. osculatum, and is also in agreement with in vitro ELISA and WB results (performed with sera with high $A$. simplex-specific IgE), where important cross-reactivity of IgE with Contracaecum proteins were evidenced.

Regarding ELISA results, the higher level of reactivity against ES proteins, when analyzed at the same concentration and conditions than SA proteins, may be due to a higher affinity to specific IgE to A. simplex ES compared to SA allergens [26]. Additionally, the similar reaction to ES proteins observed for both parasites would suggest a high similarity between Anisakis and Contracaecum IgE-epitopes, since specific anisakis-IgE generally reacts more specifically to these kind of proteins [5,27-29]. This fact would be also confirmed by the numerous Contracaecum protein bands that were revealed in the WB analysis, recognized by specific Anisakis IgE from sera in this work, and is in agreement with previous works by IgG-ELISA-based serodiagnosis [18] and by proteomic profiling [19] with both species. However, personal responses have not been studied in this work by in vitro methods, and it should be stated that the individual response against $A$. simplex and $C$. osculatum antigens could differ depending on the individual patients with allergic anisakidosis, as observed by in vivo methods.

There is enough evidence that purified allergens from A. simplex are potent enough to cause anaphylaxis in some individuals even as a result of a skin prick test with an extract of the parasite, and that allergens are also present in the flesh of fish in areas close to the larvae. In the last 20 years, it has become apparent that $A$. simplex is one of the most important hidden food allergens in the adult population suffering acute urticaria and anaphylaxis [30]. Regarding the results presented in this and previous works [19], and the practical lack of SPT-response from the other studied parasites from freshwater (Tetracotyle sp., Apophallus sp. and Posthodiplostomum sp.), attention should be focused subsequently on Contracaecum sp. and very closely related parasites, especially in order to understand future clinical situations or diagnosis/detection test developments.

We are still lacking adequate knowledge about proteins released by parasites within the genus Contracaecum and their allergenic potential, if any, which should be investigated in future studies. Other parasites may elicit IgE hypersensitivity $[17,31]$, but in the case of Contracaecum sp., no triggering of specific IgE or IgG production against SA or ES antigens have been evidenced in BALB/c mice with live larvae [24]. Nevertheless, only a few 
studies have investigated the occurrence of IgE-induced allergy to fish parasites except for A. simplex.

\section{Conclusions}

Our findings call for further studies on C. osculatum allergens for elucidation of any potential allergenicity of this parasite. Additionally, due to the suggestion that $C$. osculatum proteins may elicit reactions in some sensitized consumers, the implications of these crossreactions in relation to individualized responses, clinical significance and the development of specific diagnosis/detection tests with an immunological base should be thoroughly analyzed. Regarding food safety, the stability of antigens of this parasite when exposed to various heat and freeze processing methods commonly applied by the industry and consumers should also be examined. This information is still needed in order to understand future clinical situations as well as to establish risk assessments and, if needed, food control and safety recommendations.

Author Contributions: Conceptualization, M.Á.P. and K.B.; methodology, F.M., M.L., P.W.K., N.L., M.T.A. and K.B.; software, F.M., P.W.K. and K.B.; validation, M.L., M.T.A. and K.B.; formal analysis, F.M., M.L., P.W.K., M.Á.P., M.T.A., N.L. and K.B.; investigation, F.M., M.L., M.T.A. and N.L.; resources, M.Á.P., M.T.A. and K.B.; data curation, F.M., M.L., M.T.A. and K.B.; writing-original draft preparation, F.M. and M.L.; writing-review and editing, F.M., M.L., P.W.K., M.Á.P., M.T.A., N.L. and K.B.; visualization, F.M., M.L.; supervision, P.W.K., M.Á.P. and K.B.; project administration, M.Á.P. and K.B.; funding acquisition, M.Á.P. and K.B. All authors have read and agreed to the published version of the manuscript.

Funding: This project has received funding from the European Union's Horizon 2020 research and innovation program under grant agreement No. 634429 (ParaFishControl). This output reflects only the authors' views and the European Union cannot be held responsible for any use that may be made of the information contained herein.

Institutional Review Board Statement: This study was conducted according to the guidelines of the Declaration of Helsinki, and approved by the Ethics Committee for Clinical Research (CEIC) of the Araba Integrated Health Organization, Bioaraba (Vitoria, Spain), with internal Ref. PI2018118.

Informed Consent Statement: All participant patients gave written informed consent and patient anonymity has been secured through the entire study.

Data Availability Statement: Data supporting the analyses are available on reasonable request from the corresponding authors.

Conflicts of Interest: The authors declare no conflict of interest. The funders had no role in the design of the study; in the collection, analyses, or interpretation of data; in the writing of the manuscript, or in the decision to publish the results.

\section{References}

1. Bao, M.; Pierce, G.J.; Strachan, N.J.C.; Martínez, C.; Fernández, R.; Theodossiou, I. Consumers' attitudes and willingness to pay for Anisakis-free fish in Spain. Fish. Res. 2018, 202, 149-160. [CrossRef]

2. Audicana, M.; Kennedy, M.W. Anisakis simplex: From obscure infectious worm to inducer of immune hypersensitivity. Clin. Microbiol. Rev. 2008, 21, 360-379. [CrossRef]

3. Lozano, M.J.; Martin, H.L.; Diaz, S.V.; Manas, A.I.; Valero, L.A.; Campos, B.M. Cross-reactivity between antigens of Anisakis simplex s.l. and other ascarid nematodes. Parasite 2004, 11, 219-223. [CrossRef]

4. Perteguer, M.J.; Cuellar, C.; Guillen, L.; Aguila, C.; Fenoy, S.; Chivato, T. Cross-reactivity between Anisakis simplex sensitization and visceral larva migrans by Toxocara canis. Acta Trop. 2003, 89, 85-89. [CrossRef]

5. Guarneri, F.; Guarneri, C.; Benvenga, S. Cross-reactivity of Anisakis simplex: Possible role of Ani s 2 and Ani s 3. Int. J. Dermatol. 2007, 46, 146-150. [CrossRef] [PubMed]

6. Heffler, E.; Sberna, M.E.; Sichili, S.; Intravaia, R.; Nicolosi, G.; Porto, M. High prevalence of Anisakis simplex hypersensitivity and allergy in Sicily, Italy. Ann. Allergy Asthma Immunol. 2016, 116, 146-150. [CrossRef]

7. Johansson, E.; Aponno, M.; Lundberg, M.; Van Hage-Hamsten, M. Allergenic cross-reactivity between the nematode Anisakis simplex and the dust mites Acarus siro, Lepidoglyphus destructor, Tyrophagus putrescentiae, and Dermatophagoides pteronyssinus. Allergy 2001, 56, 660-666. [CrossRef] 
8. Pascual, C.Y.; Crespo, J.F.; San Martin, S.; Ornia, N.; Ortega, N.; Caballero, T. Cross-reactivity between IgE-binding proteins from Anisakis, German cockroach, and chironomids. Allergy 1997, 52, 514-520. [CrossRef] [PubMed]

9. Haarder, S.; Kania, P.W.; Galatius, A.; Buchmann, K. Increased Contracaecum osculatum infection in Baltic cod (Gadus morhua) livers (1982-2012) associated with increasing grey seal (Halichoerus gryphus) populations. J. Wildl. Dis. 2014, 50, 537-543. [CrossRef]

10. Mehrdana, F.; Bahlool, Q.Z.; Skov, J.; Marana, M.H.; Sindberg, D.; Mundeling, M.; Buchmann, K. Occurrence of zoonotic nematodes Pseudoterranova decipiens, Contracaecum osculatum and Anisakis simplex in cod (Gadus morhua) from the Baltic Sea. Vet. Parasitol. 2014, 205, 581-587. [CrossRef]

11. Nadolna, K.; Podolska, M. Anisakid larvae in the liver of cod (Gadus morhua) from the southern Baltic Sea. J. Helminthol. 2014, 88, 237-246. [CrossRef]

12. Zuo, S.; Kania, P.W.; Mehrdana, F.; Marana, M.H.; Buchmann, K. Contracaecum osculatum and other anisakid nematodes in grey seals and cod in the Baltic Sea: Molecular and ecological links. J. Helminthol. 2018, 92, 81-96. [CrossRef]

13. Perteguer, M.J.; Raposo, R.; Cuellar, C. In vitro study of the effect of Larval Excretory/Secretory products and crude extracts from Anisakis simplex on blood coagulation. Int. J. Parasitol. 1996, 26, 105-108. [CrossRef]

14. Mehrdana, F.; Buchmann, K. Excretory/secretory products of anisakid nematodes: Biological and pathological roles. Acta Vet. Scand. 2017, 59, 42-49. [CrossRef]

15. Mehrdana, F.; Kania, P.W.; Nazemi, S.; Buchmann, K. Immunomodulatory effects of excretory/secretory compounds from Contracaecum osculatum larvae in a zebrafish inflammation model. PLoS ONE 2017, 12, e0181277. [CrossRef]

16. Dreborg, S. Skin tests used in type I allergy testing Position paper. Sub-Committee on Skin Tests of the European Academy of Allergology and Clinical Immunology. Allergy 1989, 44, 1-59.

17. Armentia, A.; Santos, J.; Serrano, Z.; Martin, B.; Martin, S.; Barrio, J. Molecular diagnosis of allergy to Anisakis simplex and Gymnorhynchus gigas fish parasites. Allergol. Immunopathol. 2017, 45, 463-472. [CrossRef] [PubMed]

18. Kochanowski, M.; González-Muñoz, M.; Gómez-Morales, M.Á.; Gottstein, B.; Dąbrowska, J.; Różycki, M.; Cencek, T.; Müller, N.; Boubaker, G. Comparative analysis of excretory-secretory antigens of Anisakis simplex, Pseudoterranova decipiens and Contracaecum osculatum regarding their applicability for specific serodiagnosis of human anisakidosis based on IgG-ELISA. Exp. Parasitol. 2019, 197, 9-15. [CrossRef] [PubMed]

19. Kochanowski, M.; Dabrowska, J.; Różycki, M.; Karamon, J.; Sroka, J.; Cencek, T. Proteomic Profiling Reveals New Insights into the Allergomes of Anisakis simplex, Pseudoterranova decipiens, and Contracaecum osculatum. J. Parasitol. 2020, 106, 572-588. [CrossRef]

20. Nagasawa, K. The biology of Contracaecum osculatum sensu lato and C. osculatum A (Nematoda: Anisakidae) in Japanese waters: A review. Biosphere Sci. 2012, 51, 61-69.

21. Schaum, E.; Müller, W. Heterocheilidiasis (case report). Deut. Med. Wochenschr. 1967, 92, 2230-2233. [CrossRef]

22. Shamsi, S. Parasite loss or parasite gain? Story of Contracaecum nematodes in antipodean waters. Parasite Epidemiol. Control 2019, 3, 1-7. [CrossRef] [PubMed]

23. Shamsi, S.; Butcher, A.R. First report of human anisakidosis in Australia. Med. J. Aust. 2011, 194, 199-200. [CrossRef] [PubMed]

24. Vericimo, M.A.; Figueiredo, I.; Teixeira, G.A.; Clemente, S.C. Experimental anisakid infections in mice. J. Helminthol. 2015, 89, 620-624. [CrossRef] [PubMed]

25. Buchmann, K.; Mehrdana, F. Effects of anisakid nematodes Anisakis simplex (s.l.), Pseudoterranova decipiens (s.l.) and Contracaecum osculatum (s.l.) on fish and consumer health. Food Waterborne Parasitol. 2016, 4, 13-22. [CrossRef]

26. Baeza, M.L.; Rodríguez, A.; Matheu, V.; Rubio, M.; Tornero, P.; De Barrio, M.; Herrero, T.; Santaolalla, M.; Zubeldia, J.M. Characterization of allergens secreted by Anisakis simplex parasite: Clinical relevance in comparison with somatic allergens. Clin. Exp. Allergy 2004, 34, 296-302. [CrossRef]

27. Carballeda-Sangiao, N.; Rodriguez-Mahillo, A.I.; Careche, M.; Navas, A.; Caballero, T.; Dominguez-Ortega, J. Ani s 11-Like Protein Is a Pepsin- and Heat-Resistant Major Allergen of Anisakis spp. and a Valuable Tool for Anisakis Allergy Component-Resolved Diagnosis. Int. Arch. Allergy Immunol 2016, 169, 108-112. [CrossRef]

28. Caballero, M.L.; Moneo, I. Specific IgE determination to Ani s 1, a major allergen from Anisakis simplex, is a useful tool for diagnosis. Ann. Allergy Asthma Immunol. 2002, 89, 74-77. [CrossRef]

29. Caballero, M.L.; Moneo, I.; Gomez-Aguado, F.; Corcuera, M.T.; Casado, I.; Rodriguez-Perez, R. Isolation of Ani s 5, an excretorysecretory and highly heat-resistant allergen useful for the diagnosis of Anisakis larvae sensitization. Parasitol. Res. 2008, 103, 1231-1233. [CrossRef]

30. Audicana, M.T.; Girao, I.; Longo, N. Anisakis simplex, a new hero in the anaphylaxis scene. J. Emerg. Med. Crit. Care 2017, 1, 1008.

31. Fontenelle, G.; Knoff, M.; Vericimo, M.A.; Sao Clemente, S.C. Epicutaneous sensitization with nematode antigens of fish parasites results in the production of specific IgG and IgE. J. Helminthol. 2017, 92, 403-407. [CrossRef] [PubMed] 